\title{
Diverse Voices and Democratic Policymaking: What Causes Japan's Nuclear Phase-Out Plan to Fail?*
}

\author{
Mikiko Eto \\ Hosei University, Tokyo, Japan
}

\begin{abstract}
The nuclear disaster at Fukushima has raised questions about the nature of democratic policymaking in Japan. Focusing on nuclear policymaking post-Fukushima, this paper considers ways in which the diversity of public opinion can be connected with legislative processes. The disaster forced the government to rethink existing nuclear policies. To infuse public voices into government policy, the Democratic Party of Japan (DPJ) government introduced a new method of public participation called "national debates", comprising a series of public hearings, mass public comments, and deliberative polling. The government also attached importance to anti-nuclear rallies and opinion polls conducted by the media. The national debates highlighted that the majority of Japanese people supported a nuclear-free society; as a result, the government drafted a new energy plan to phase out nuclear power by 2039. Owing to both domestic and international opposition, the plan failed to become law. Progress was also impeded by the public's contradictory demands. However, this paper posits that inefficient legislative deliberation was the main factor behind the policy failure. The Japanese case suggests that effective legislative deliberation is crucial to assessing and coordinating numerous divergent public voices.
\end{abstract}

Keywords: public debates, contradictory demands, democracy, nuclear policy, Fukushima, Japan

\section{Introduction}

Public disaffection with representative democracy appears to be globally widespread. In recent years, we have witnessed citizens making political demands through a participatory style of activism outside legislatures. However, this is not a new event in advanced countries; in fact, a similar tendency emerged over four decades ago. Empirically comparative studies in North America, Western Europe, and Japan have demonstrated that, despite a clear trend of a mounting distrust of politicians, a decline in party identification, absence from polling stations, and disaffection with parliaments, citizens engage in diverse styles of democracy, such as town meetings, public fora, rallies, and collecting signatures and petitions (e.g., Crozier, Huntington, \& Watanuki, 1975; Pharr \& Putnam, 2000). In advanced societies, many citizens are discontented with representative democracy. They do not lose faith in the values of democracy or democratic politics but seek to put democracy into practice through direct involvement in politics (Inglehart, 1999; Dalton, 2000).

Why do these citizens prefer direct involvement to representative institutions? Inglehart (1999) and Dalton

\footnotetext{
* Acknowledgements: I appreciate the Nordic Institute of Asian Studies and the Australian Political Studies Association 2014 Annual Conference that provided me with opportunities to present my ideas of this study, on September 2, 2013 and September 29, 2014, respectively. I would like to give special thanks to my three interviewees, Masakatsu Ota, Masao Matsumoto, and Motohisa Furukawa. I am also grateful to Akihiro Ogawa, Atsushi Sugita, and Gil Merom for their helpful comments.

Mikiko Eto, Ph.D., Professor, Faculty of Law, Hosei University.
} 
(2000) offered an explanation in terms of citizens' autonomous attitudes toward democratic politics, referring to these citizens as "postmodernists" and "postmaterialists", respectively. Post-modern/post-material citizens, who are well educated, enjoy material affluence, live within a highly information-oriented society, and no longer follow any authority in their decision-making. Instead, they aim to engage in political decision-making and make their voices heard. Moreover, they are divergent in their political demands, and some of their demands are inconsistent with other demands. As the legislatively representative system is not always responsive to their diverse demands, citizens choose to represent their demands themselves. Political activities outside legislative bodies provide citizens with a platform by which to deliver their opinions to the center of policymaking, thus by passing legislative representatives. Notwithstanding the potential of citizens' political activism to strengthen democracy and of their self-actualization, a question remains regarding how their different and contradictory voices can be integrated into public policy or of how civic participatory activities outside legislatures could work in harmony with legislative representation.

This paper aims to tackle the abovementioned question through a case study of Japan's national debates on nuclear policy. The nuclear disaster at Fukushima on March 11, 2011 forced Japan to rethink its energy policy. Specifically at issue was whether the generation of nuclear power should be abolished or retained. In order to establish national consensus on nuclear generation, the government of the Democratic Party of Japan (DPJ) implemented a civic participation method called "national debates", comprising three programs-public hearings, public comments, and deliberative polling-mobilizing approximately 97,000 people in summer 2012. These programs indicated that the majority of Japanese people desired a safe society without nuclear power. Opinion polls conducted by the media also presented similar results. Outside the government, meanwhile, a couple of hundred thousand Japanese joined anti-nuclear rallies. In this regard, the DPJ government made a new energy plan for phasing out nuclear generation by 2039 hereafter called the nuclear-phase-out plan. However, as the government failed to make this plan law to guarantee its implementation, a regime change overturned the plan. The Liberal Democratic Party (LDP), which came into power by a landslide victory in the general election of December 2012, proposed a pro-nuclear plan to scrap the DPJ's nuclear-phase-out-plan.

This paper explores what discouraged Japan from moving toward a society without nuclear power and why the same citizens who had opposed nuclear power supported a pro-nuclear party. In this inquiry, the author focuses on a dispute over nuclear (power) policy between the public, the government, and the nuclear industry. A dispute, as Skinner (1988) noted, is not merely a linguistic matter; rather, it has the potential to cause substantive social change. Skinner (1988) called such dynamism of verbal disputes, "speech-act potential" (p. 128). Connolly (1993) also noted, "conceptual contests are central to politics" and "they provide the space for political interaction" (p. 6). In this way, politics is a process of contestation involving socio-political instability and change.

Three phrases describe the language employed in Japan's dispute over nuclear power: pro-nuclear, anti-nuclear, and nuclear renouncement. The first phrase literally means to advocate nuclear power or promote nuclear energy policy. Although the second two are negative terms that oppose nuclear power and pursue a nuclear-free society, their ideas and uses are different. The phrase "anti-nuclear" denotes that nuclear power should be abolished immediately because it is unnecessary for society; whereas, "nuclear renouncement" indicates the desire to cease relying on nuclear power generation because its demerits surpass its benefits. While the former assumes an ideologically strong sense uttered by social movement activists and their supporters, the latter is a milder phrase with an ideologically neutral stance, which is thus accepted by many 
more people. The public, the government, and the industry have used these phrases according to their interests, opinions, and political circumstances. Whenever they agree or disagree with one another regarding nuclear policy courses, the three phrases are always centered on their dispute.

The remainder of this paper comprises three sections. Section One describes how people have increasingly accepted nuclear power despite doubts about its safety even before the Fukushima disaster, and elucidates that a small group of people benefitting politically and economically from nuclear generation exclusively developed Japan's nuclear policy. Section Two explains how the national debates were performed by identifying public voices at two different levels: government-sponsored national debates and anti-nuclear rallies. Section Three investigates the reasons for the failure of the nuclear-phase-out plan, demonstrating that in addition to the socio-political complexities and constraints that surround policymaking, the contradictory demands of the public were a setback for achieving the nuclear phase-out plan; thus, the inconsistency of public demands is the main obstacle to realizing a nuclear-free society. However, the Japanese public is not to blame for their inconsistent demands. As noted earlier in this section, the postmodern/postmaterial citizens raised diverse and contradictory voices. This paper views insufficient legislative deliberation rather than public contradictory voices as problematic in policymaking, and concludes by suggesting that legislative representatives take responsibility for ensuring the reflection of consensus in policy outcomes through serious debates on the issue.

\section{Public Ambivalence Toward Nuclear Power, Pre-Fukushima}

The people of Japan were originally doubtful about nuclear power. The tragedies of the atomic bombs in Hiroshima and Nagasaki had implanted a strong national fear of and hostility toward atomic power. Such emotions are often called the "atomic allergy". This allergy was reinforced by an accident in which the crews of a Japanese fishing boat were exposed to radiation from a US thermonuclear test on Bikini Atoll on March 1, 1954. Immediately after the accident, an anti-nuclear sentiment spread throughout the country. People actively engaged in collecting signatures to demand a ban on the development of any nuclear bomb. The signatures reached 32,380,000 by August 1955.

Despite the public's negative opinion, the Japanese government undertook the commercial use of nuclear power generation because of a political power game (Yoshioka, 2012, pp. 69-80; Yamaoka, 2012, pp. 26-89). The mid-1950s saw the rapid institution of a program of nuclear development, and the LDP developed Japanese nuclear policy. ${ }^{1}$ The first nuclear reactor in Japan was installed in October 1963 and became operational in July 1966. Since then, the LDP government has promoted nuclear policy.

Some residents of the municipalities wherein nuclear plants were installed became worried about nuclear safety, and as a result, became involved in anti-nuclear actions. In August 1975, the residents held the first nationwide meeting to campaign against nuclear power in Kyoto. Before this meeting, on May 16, 1975, Asahi Newspaper, the leading nationwide newspaper in Japan, published an article stating that municipality-based anti-nuclear groups planned to organize themselves as a nationwide federation. In the 1970s, Asahi Newspaper published 30 anti-nuclear articles. ${ }^{2}$ A nuclear accident at Three Mile Island in March 1979 spurred Japanese

\footnotetext{
${ }^{1}$ Except for several leaders who have adopted neo-liberal courses, the LDP is ideologically conservative but pursues economic growth by encouraging public investment and protecting key industries.

${ }_{2}^{2}$ Sourced from Asahi Newspaper archive, called kikuzo II, searched between January 1, 1970 and December 31, 1979. Retrieved from

https://vpn.hosei.ac.jp/+CSCO+00756767633A2F2F716E676E6F6E66722E6E666E75762E70627A++/library2/main/-CSCO-30-top.php (the final access is on June 10, 2016).
} 
public opposition to nuclear plants. A more serious accident at Chernobyl in April 1986 stirred further anxiety amongst the Japanese public. The Chernobyl disaster broadened anti-nuclear sentiments to the wider society outside the municipalities holding nuclear plants. Mothers, in particular, worried about the adverse effects of nuclear radiation on their children's health, and consequently, a large number of young mothers got involved in anti-nuclear movements (Eto, 2008).

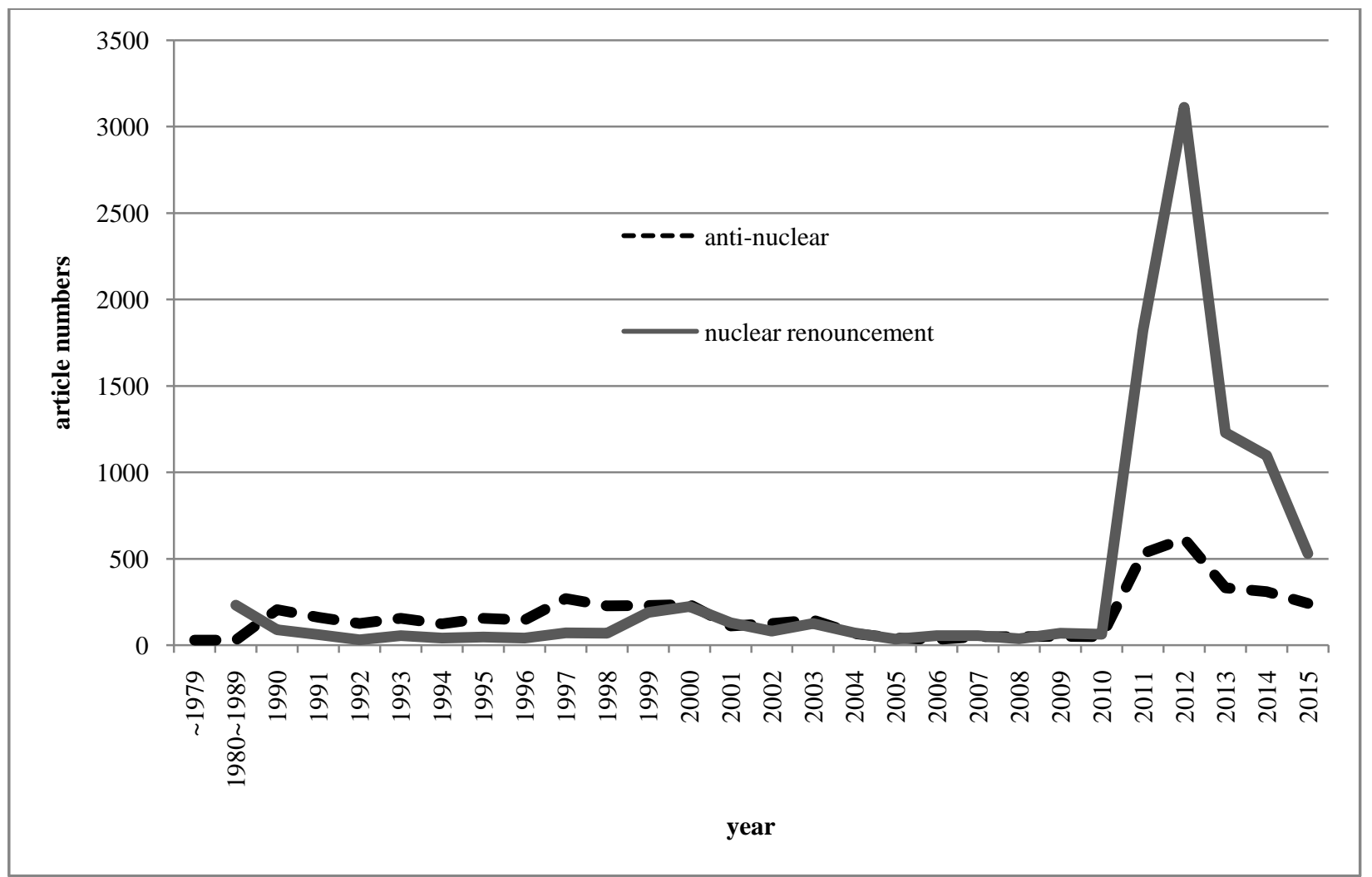

Figure 1. The number of articles including the negative phrases of nuclear power seen year by year (Sourced from Asahi Newspaper archive, called kikuzo II).

The Chernobyl disaster brought about another negative nuclear phrase, "nuclear renouncement", to Japanese society. Asahi Newspaper first carried an article referring to this phrase on July 14, 1986. The Asahi article introduced the viewpoint that Japan should not lag behind West Germany in the realization of a nuclear-free society. ${ }^{3}$ The phrase "nuclear renouncement" infiltrated gradually into Japanese society. During the 1990s, Japanese nuclear plants caused various problems: ${ }^{4}$ incidents happened in 1991, 1995, and 1997; and accidents occurred in 1999. In addition to the Chernobyl disaster, these nuclear problems stimulated the media to pay attention to the phrases: "anti-nuclear (power)" and "nuclear (power) renouncement". The frequency of references to the negative phrases in Asahi Newspaper's articles increased in the 1990s (see Figure 1).

\footnotetext{
${ }^{3}$ Sourced from Asahi Newspaper archive, called kikuzo II, searched between January 1, 1970 and December 31, 1979. Available at https://vpn.hosei.ac.jp/+CSCO+00756767633A2F2F716E676E6F6E66722E6E666E75762E70627A++/library2/main/-CSCO-30-top.php (the final access is on June 10, 2016).

4 According to the International Atomic Energy Agency, nuclear problems are categorized into seven levels. The higher the level, the higher the seriousness of the trouble. The three lower levels, 1 to 3, are identified as "incidents", while the four higher levels, 4 to 7, are defined as "accidents". Available at http://www-ns.iaea.org/tech-areas/emergency/ines.asp (the final access is on June, 2016).
} 
However, the anti-nuclear movement failed to spread across the country and was limited to regional levels. Throughout the 1990s, 64 civic groups based in 33 areas, mostly in locations of nuclear power plants, campaigned against nuclear power to dismantle the plants (Hangenpatsu undozenkokurenrakukai, 1997).

Despite the Japanese public's concern about nuclear safety, their atomic allergy did not recur, suggesting that they came to accept nuclear power generation as a practical source of energy. Opinion polls conducted by the Japanese government demonstrate that public support for nuclear power generation increased year on year. The proportions of those who agreed with the use of nuclear generation were $38.5 \%$ in $1975,47 \%$ in 1980 , $64.5 \%$ in $1990,75.3 \%$ in 2005 , and $78.4 \%$ in $2009 .{ }^{5}$ Kitada (2013) confirmed this trend by analyzing the changes in Japanese public opinion. ${ }^{6}$ Kitada (2013, pp. 178-179) pointed out that the proportion of those who disapproved of nuclear generation between 1978 and 2010 stayed between $20 \%$ and 30\%, concluding that even visible nuclear accidents, such as the Three Mile Island accident and the Chernobyl disaster, did not have a negative impact on public attitudes toward nuclear power. However, the public's anxiety about nuclear safety remained in their minds. According to the abovementioned government surveys, $47 \%$ of respondents answered that they were worried about the safety of nuclear power stations in $1980,46.8 \%$ in $1990,65.9 \%$ in 2005 , and $53.9 \%$ in $2009 .^{7}$

Why did many Japanese people who were not trustful of nuclear safety resign themselves to their energy reliance on nuclear generation? This is mainly because of the government's success in creating a myth of nuclear safety; that is, the safety of nuclear power plants was given a condition about which people were prevented from discussing or having any doubts (Suzuki, 2012a, p. 324). According to Kazuto Suzuki (2012b, pp. 296-297), who examined socio-cultural factors in the Fukushima disaster, the mythology originated from the lack of established nuclear safety regulations, specifically regulations pertaining to the eviction of residents from the areas around nuclear plants. When the LDP government undertook the installation of nuclear plants in the 1960s, the government assured residents living around the plants that it was safe to remain in their homes despite a lack of confidence in the safety of the plants. The residents had no choice but to believe that it was safe and continued their everyday life as usual. The government and the majority of the public assumed that no accident would occur.

A secret machinery of nuclear policymaking, which shared the same interests in developing nuclear policy, contributed to mystifying nuclear safety. This policymaking machinery exclusively comprised groups that sought to benefit from promoting nuclear policy, such as electric companies, the nuclear industry, national and local politicians whose constituencies were invested in the benefits of nuclear power, ministries in charge of nuclear public administration, and nuclear science academia. The machinery exercized a dominant influence on Japan's energy policy by initiating policy agendas and managing conflicting interests among its members before submitting the policy to the Diet (Japanese national parliament). The policymaking machinery often monopolized important information about nuclear policy, particularly safety, to protect its interests from people or groups against nuclear power. In this regard, the community is metaphorically referred to as the "Nuclear

\footnotetext{
5 The data derive from the following surveys: The Japan Atomic Energy Commission, 1976; 1982; the Prime Minister's Office, 1990; the Cabinet Office, 2005; 2009. Available at http://www.aec.go.jp/jicst/NC/(the final access is on April 21, 2016).

${ }^{6}$ Kitada analyzed nine opinion polls of the government, mass media, and non-governmental research agencies on nuclear power. Since these surveys used different questionnaires, she adjusted them by dichotomizing them into affirmative and negative wordings.

7 The data derive from the following surveys: The Japan Atomic Energy Commission, 1976; 1982; the Prime Minister's Office, 1990; the Cabinet Office, 2005; 2009. Available at http://www.aec.go.jp/jicst/NC/(the final access is on April 21, 2016).
} 
(Power) Village ${ }^{8 \% " ~(S u z u k i, ~ 2012 a, ~ p p . ~ 323-334 ; ~ S a m u e l s, ~ 2013, ~ p p . ~ 118-119) . ~ M o s t ~ J a p a n e s e ~ p e o p l e ~ w e r e ~}$ unaware that such informal machinery existed behind formal policymaking institutions until the Fukushima disaster. Its invisibility was useful for perpetuating the fact that nuclear safety was uncertain.

The LDP government introduced a new program to cope with public anxiety about safety. The program aimed to encourage public participation in nuclear policymaking, which allowed anyone to submit his/her opinion to the government when a new nuclear policy was drafted in 1996. However, the government refused to accept public opinions opposing a government draft, reflecting only those demanding minor changes to the draft (Yoshioka, 2012, pp. 261-291). Clearly, the Nuclear Village still had a powerful influence on nuclear policymaking. Most Japanese people were excluded not only from participating in the nuclear policy discussion but also accessing information about the process, such as who initiated a nuclear policy proposal, why the proposal was necessary, and how it could benefit them in their everyday lives. The public merely received government-provided information disseminated to underscore the usefulness of nuclear energy given the country's shortage of natural resources and to emphasize the safety of nuclear plants. The message that nuclear energy could compensate for a shortage of natural resources to enhance the Japanese economy was convincing to the Japanese public. As a result of having its attention diverted so compellingly from the dangers of nuclear technology, the Japanese population began to passively accept nuclear power.

The victory of the DPJ in the general election of 2009 broke the LDP's dominance, and the new DPJ government took over the LDP's nuclear policy. Like its predecessor, the DPJ treated nuclear power not only as a key energy source but also as a promising industry for economic growth (Yamaoka, 2012, pp. 218-221). The Nuclear Village continued to retain an exclusive influence on nuclear policy. In the first half of the 2000s, as shown in Figure 1, Asahi Newspaper published articles on anti-nuclear and nuclear renouncement as frequently as in the previous decade. In the second half of the 2000s and 2010, however, the number of Asahi's articles on these negative phrases had declined remarkably. As the myth of nuclear safety came to look as if it was a truth, the Japanese public's anxiety seemed to fade from their minds. This public move supported the DPJ government's pro-nuclear policy.

The Copenhagen Climate Change Conference in December 2009 spurred Japan's reliance on nuclear power. At the conference, Prime Minister Yukio Hatoyama, who had been newly nominated in September 2009, promised that Japan would reduce its $\mathrm{CO}_{2}$ emissions to $25 \%$ of 1990 levels by 2020 . At that time, 35 reactors were operational, providing approximately $26 \%$ of the country's electricity. To meet Hatoyama's promise, the Basic Energy Plan ${ }^{9}$ of 2010 stipulated that nuclear power was a key energy source that could satisfy the three principles of the national energy policy - sustainable provision, suitability for the environment, and economic efficiency. Following this plan, the DPJ government decided to increase nuclear generation so that it would account for $45 \%$ of Japan's electricity production by 2030 .

\section{Rising Voices Calling for a Nuclear-Free Society}

The Fukushima disaster suddenly broke Japan's superficial calmness surrounding nuclear safety bringing great fear of nuclear power to the forefront of Japanese public opinion. Japanese people realized that they had

\footnotetext{
8 The Japanese word "village (mura)" connotes an exclusive group of people with the same goal, where the members monopolize information or benefits, detaching themselves from wider society.

9 The government based the Basic Energy Plan on the Basic Act on Energy Policy. It is renewed every three years and needs to be approved by the cabinet. The plan is available at http://www.meti.go.jp/committee/summary/0004657/energy.pdf (the final access is on April 13,2016).
} 
to live with an extraordinary risk as long as they relied on nuclear power. Their doubts about nuclear safety, which had been assuaged by the myth of nuclear safety, appeared with a strong rage against the Nuclear Village. They thought that the existing pro-nuclear policy was too risky to put into practice. Revision of the existing energy policy was placed firmly on the national agenda. However, there was no agreement as to whether nuclear power should be abolished entirely; and if not, the degree to which it should remain. This issue polarized the nation. Here, this paper examines the key debates surrounding nuclear policy, dividing them into two stages: the grassroots initiatives and the government-led initiative.

\section{Citizens' Anti-Nuclear Discourse}

The Fukushima disaster sparked an anti-nuclear movement mobilizing many more people than did the Chernobyl disaster. Collective anti-nuclear actions, such as gatherings and demonstrations, spread throughout the country. This movement post-Fukushima developed from relatively small-scale groups of around several hundred community-based groups in different areas acting on an individual basis. However, less than a year after the disaster, the decision of the DPJ government to resume the operation of reactors triggered these groups to integrate into an action network and even coordinate a joint protest rally.

Following the disaster, the operations of active reactors were suspended one-by-one, with the aim of suspending all reactors by May 2013. However, out of concern for potential electricity shortages in the heat of the summer, the government planned to reactivate two reactors at Ohi Plant that passed the safety test. In late March 2012, the government announced that four Cabinet members involved in the matter- the Prime Minister; the Minister of Economy, Trade and Industry; the Minister in charge of nuclear issues; and the Chief Cabinet Secretary-would discuss the possibility of reactivating the reactors. Anti-nuclear civic groups reacted to this announcement immediately. Two such groups, named "No Nukes More Hearts" and "Twit-No-Nukes", comprising 300 participants, protested against the reactivation in front of the Prime Minister's Office on March 29, 2012. A similar protest took place at the same location on Friday April 6, 2012, mobilizing 1,000 people. Subsequent rallies held in front of the Prime Minister's Office every Friday came to be known as the "Friday Rallies". As Table 1 describes, the number of participants increased steadily following the government announcement that Ohi Plant would reopen on July 1, 2012, reaching between 150,000 and 200,000 in July. The rallies became the largest social movements of the post-war period. ${ }^{10}$

These citizens' movements prompted anti-nuclear Diet members-including the former Prime Minister, the former Minister of Justice, and Opposition leaders - to join the Friday Rallies, and their speeches demonstrated the strong competition between them. The rallies' activists also invited a core group from the Friday Rallies, called the Tokyo Alliance of Nuclear Power, to exchange viewpoints on nuclear-free policy. On July 31, 2012, 23 representatives of the anti-nuclear Diet members and the Friday Rallies participated in a meeting. While the activists' views did not dovetail with those of politicians, the two parties agreed that Prime Minister Yoshihiko Noda ${ }^{11}$ should listen to the voices of the many citizens who were worried about nuclear safety (Noma, 2012, pp. 201-208). Prime Minister Noda finally decided to meet representatives of the rallies to hear their causes in person. On August 22, 2012, 10 representatives of the rallies met with the prime minister and asked him not to re-open the Ohi Plant. The prime minister listened to their request sincerely but he made

\footnotetext{
${ }^{10}$ In 1960, Japanese protesters denounced the Japan-US Security Treaty. Nationwide trade unions mobilized five million workers to go on general strikes. However, the number of people who participated in protest demonstrations in front of the Diet Building remained at around ten thousand.

11 Noda took office as the Prime Minister on September 2, 2011.
} 
no promises (Noma, 2012, pp. 216-227). Nevertheless, the dialogue between the prime minister and anti-nuclear activists sent the Japanese public a message that the government gave weight to public anti-nuclear sentiments.

Table 1

Anti-Nuclear Rally in 2012: The Movements of the Friday Rallies in Front of the Prime Minister's Office

\begin{tabular}{|l|l|l|}
\hline Date & Mobilization & Relevant event \\
\hline March & & The government planned to reopen the Ohi plant \\
\hline 29 March & 300 participants & \\
\hline 6 April & 1,000 participants & \\
\hline Late June & $\begin{array}{l}150,000-200,000 \\
\text { participants }\end{array}$ & Attracted media attention \\
\hline Early July & & Supra-partisan parliamentarians attended \\
\hline 20 July & & The former prime minister, Yukio Hatoyama, attended \\
\hline 31 July & & $\begin{array}{l}\text { Representatives of the rally were involved in discussion with two supra-partisan groups } \\
\text { of anti-nuclear parliamentarians }\end{array}$ \\
\hline 22 August & & \begin{tabular}{l}
10 representatives of the rally met Prime Minister Noda to promote their causes directly \\
\hline
\end{tabular}
\end{tabular}

Notes. Sourced from Noma 2012: Appendix. ${ }^{*}$ The numbers of participants in the protest rally against nuclear power.

The two negative nuclear phrases immediately became familiar to ordinary Japanese people, as the phrases of "anti-nuclear" and "nuclear renouncement" filled the new coverage. As Graph 1 shows, the number of Asahi Newspaper articles including these phrases increased dramatically, reaching a peak in 2012. Similar to the activists' reaction, the government plan to reactivate the reactors stimulated public antipathy toward nuclear power, which was intensified by an upsurge in the anti-nuclear rallies (see Table 1). Synchronized with such sentiments of Japanese people, the articles including the two phrases rapidly increased. The graph also demonstrates that Asahi articles have quoted the phrase "nuclear renouncement" much more frequently than the phrase "anti-nuclear" since the Fukushima disaster. As noted in the introduction, the former phrase sounds more moderate and ideologically neutral than the latter, thus allowing those who were reluctant to be identified with activists or politicized citizens to speak out for their causes. The prevalence of the phrase "nuclear renouncement" indicates the increasing disapproval of nuclear power among non-activists or apolitical people.

\section{Government-Sponsored National Debates}

The Fukushima disaster prompted the DPJ government to change the method of nuclear policymaking that had been inherited from the LDP. The government decided to draft a new energy policy after listening to a number of diverse public voices. To draft the new policy, the government established the Energy and Environment Council, composed of seven ministers related to the matter, in October 2011. The National Policy Unit attached to the Cabinet Office was in charge of the Council's administration. The Council, which sought to determine the ideal composition of Japan's sources of electric energy for the year 2030, was faced with the task of judging the proportion of electricity that should be generated from nuclear power, while taking into account public opinion. To gauge public opinion on the new policy, the government instituted a novel approach of increasing civic participation through "national debates", which allowed many more Japanese people to submit their opinions and ideas to the government.

The phrase "national debates" was not new in the Diet sessions. It was first used in the Upper House Cabinet Committee meeting held on May 12, 1970 by Tetsu Ueda of the Japan Communist Party during a 
discussion of national security. The term came to prominence in the 1990s. ${ }^{12}$ However, the phrase had been merely nominal without any substantive weight until 2012. The main reason the DPJ government adopted the national debates was to create a more open policymaking style, which incorporated the opinions of the general public, as Japanese people had begun to consider that the closed-door approach to nuclear policy formation was responsible for the disaster. Promoting civic participation in the policymaking process was consistent with the DPJ's political style, as the DPJ government had already implemented a civic participation program to the administrative screening process in 2010. Moreover, Diet members from opposition parties called for national debates on new forms of energy production, and consequently supported the ruling DPJ's decision. ${ }^{13}$

At the Upper House Environment Committee meeting held on September 15, 2011, Prime Minister Noda noted that, based on the national consensus, his administration planned to use input from the national debates to judge the degree by which nuclear generation should be reduced. The Policy Unit in charge of national debates issued a working paper to guide the debates, titled "Options for Drafting the Energy and Environment Policy", in July 2012 (National Policy Unit, 2012). The working paper included four policy agendas to achieve by 2030: reducing the degree of reliance on nuclear generation, providing sustainable energy, contributing to the mitigation of global warming, and balancing energy costs with economic growth.

The national debates centered on the realization of the first policy agenda and the reduction of reliance on nuclear power (National Policy Unit, 2012). The working paper proposed three options: Option 0 to abolish nuclear power and create a nuclear-free society by 2030, Option 15 to reduce the percentage of nuclear power to $15 \%$ by 2030 , or Option $20-25$ to reduce the percentage of nuclear power to $20 \%-25 \%$ by 2030 . All three options would satisfy the abovementioned four goals by 2030. The working paper also examined the economic impacts of the three options. Four independent institutions estimated the effects of each option on GDP and found that all options - even Option 0 - would raise GDP in the future. The government implemented national debates by means of three programs, namely public hearings, public comments, and deliberative polling, between July 2 and August 26, 2012 (see Table 2). In these three programs, the participants either presented their preferred option by giving each a number on a scale of 0 to 10 or discussed the three options to find the one they most preferred.

Public hearings held at 11 cities between July 14 and August 4, 2012 aimed to let people state their preferred option and general opinions of nuclear policy to the government. Of 1,542 applicants, 136 volunteers were selected to present their preferred option and general opinions on nuclear power to government officials in person, and 1,276 participants answered questionnaires on the three options. Through public comments, individuals sent email messages detailing their choices to the government. Surprisingly, the government received 88,286 responses between July 2 and August 12 . These two programs were familiar to the Japanese public administration. When the government plans to form a new policy or reform an existing policy, it implements these programs to gauge public opinion, particularly those affected by the policymaking. Despite this process, the government had failed to take the public's voices seriously before. Nevertheless, the national government ${ }^{14}$ first adopted deliberative polling because the other two programs were likely to attract those

\footnotetext{
12 Sourced from the Diet record search engine, Kokkaigijirokukensakushisutemu. Available at http://kokkai.ndl.go.jp/(the final access is on 16 March, 2016).

${ }^{13}$ Sourced from the Diet record search engine, Kokkaigijirokukensakushisutemu. Available at http://kokkai.ndl.go.jp/(the final access is on 16 March, 2016).

${ }^{14}$ At the local level, some municipalities have introduced deliberative polling under the guidance of Keio University, see the Center for Deliberative Polling, Keio University. Available at http://keiodp.sfc.keio.ac.jp/(the final access is on March 1, 2016).
} 
with strong anti-nuclear opinions. The government attempted to mitigate the strong voices and comments of the anti-nuclear participants in the public hearing with the expectation that deliberative polling, which selected participants randomly, would represent relatively neutral voices.

Table 2

The Three Schemes for Publically-Sponsored National Debates

\begin{tabular}{|l|l|l|l|}
\hline & Public Hearings & Public Comments & Deliberative Polling \\
\hline Date to be held & July 14 to August 4 & July 2 to August 12 & $\begin{array}{l}\text { 1st phase: July 7 to 22 } \\
\text { 2nd phase: August 4 and 5 }\end{array}$ \\
\hline Procedure & $\begin{array}{l}\text { Held in 11 cities } \\
\text { Group A: Presenting their preferred option } \\
\text { Group B: Answering questionnaires on the } \\
\text { preferred option }\end{array}$ & $\begin{array}{l}\text { Sending opinions with } \\
\text { preferred option to the } \\
\text { government by email }\end{array}$ & $\begin{array}{l}\text { 1st phase: Answering questionnaires } \\
\text { on the preferred option } \\
\text { 2nd phase: Deliberative forum }\end{array}$ \\
\hline Number of participants & $\begin{array}{l}\text { Group A: 136 } \\
\text { Group B: 1,276 }\end{array}$ & 88,286 & $\begin{array}{l}\text { 1st phase: 6,849 } \\
\text { 2nd phase: 286 }\end{array}$ \\
\hline
\end{tabular}

Deliberative polling, which started with telephone surveys between July 7 and 22, 2012, randomly sampled 6,849 people over the age of 20 nationwide to answer questionnaires on nuclear power ${ }^{15}$ by ranking the three options in order of preference. The participants were also asked to participate in a deliberative forum. Of those surveyed, 286 respondents ${ }^{16}$ volunteered to take part in the two-day deliberation on August 4 and 5. The participants answered the same questionnaires before and after the forum so that any changes in their opinions during the deliberative process could be examined. The 286 participants were divided into 19 small groups. The forum comprised two processes: free discussions within each small group of 15 or 16 members, and general meetings with all participants and experts on nuclear power, renewable energy, and the economic costs of electricity. The general meetings, held after the group discussions, aimed to provide technical knowledge and information to the participants and answer any questions that came out of the discussions. During the two-day forum, the group discussions and general meetings were carried out twice, with all sessions taking one and a half hours.

In the government-sponsored questionnaires, the respondents did not choose between the three options but scored each option out of ten. The highest scored option became their choice; for example, if a participant assigned 7 points to Option 0, 5 points to Option 15, and 4 points to Option 20-25, he/she was considered to choose "Option 0" as their preferred option. Figure 2 shows the proportion of each of the three options that the participants chose by giving it their highest score among the three programs. The proportion of respondents with Option 0 tended to be higher among the voluntary participants/respondents than among the randomly selected participants/respondents, although each proportion presents different results. Whereas the proportion of participants with Option 0 represents $87 \%$ of the public comments and $68 \%$ of participants who presented their opinions in the public hearings, these figures dropped to $27 \%$ and $35 \%$, respectively, in the telephone survey, the deliberative polling and the questionnaires in the public hearings. Why did the voluntary participants/respondents support Option 0 more than did the randomly selected participants/respondents? Those who opposed nuclear power more seriously sought to make use of an opportunity to promote their cause. Indeed, an anti-nuclear group named “Goodbye to Nuclear Power by 10 Million Citizens' Action” requested its

\footnotetext{
15 This deliberative polling was guided by the Center for Deliberative Polling, Keio University. Available at http://keiodp.sfc.keio.ac.jp/?page_id=243(the final access is on March 1, 2016).

16 One out of 286 people only participated in the first half of the two-day deliberation.
} 
supporters to send their choice of Option 0 to the public comments office. ${ }^{17}$ The voluntary participants were more likely to support Option 0 than the average Japanese public.

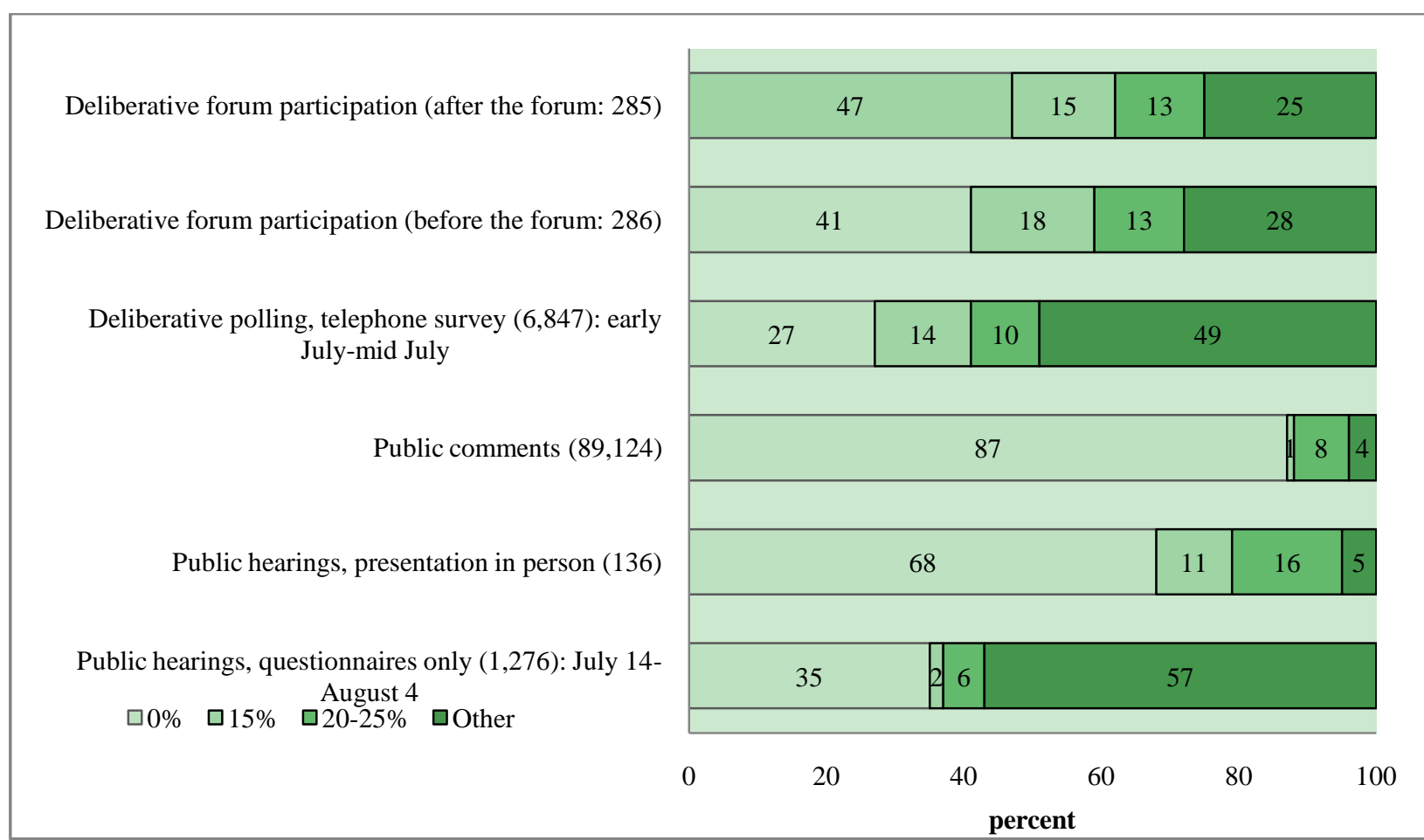

Figure 2. Proportions of three options concerning Japan's energy reliance on nuclear generation in 2030, at the events sponsored by the government. Sourced from the National Policy Unit, http://www.env.go.jp/council/06earth/y060-110/mat01_1.pdf.

In Figure 2, the two top bars demonstrate the change of opinions before and after the deliberative forum. After the forum, the proportion of participants who preferred Option 0 increased by 6 points to $47 \%$, while $3 \%$ of Option 15 and Other ${ }^{18}$ shifted to Option 0. The proportion of Option 20-15 did not change. The deliberation slightly shifted participants' opinions toward the anti-nuclear cause.

In addition to the three programs, the government conducted interviews with 58 interest groups, such as business executive groups, trade unions, consumer groups, and pro-environment groups, to canvas their opinions between July 2 and August 26. The interviews revealed that, while vocational interest groups including business executive groups and trade unions tended to disagree with Option 0 and wished to maintain the existing level of nuclear power, citizens' groups, including those based around consumers and pro-environmental policy, insisted on Option 0.

The Japanese media conducted opinion polls on the three options by means of random selection telephone surveys between early July and late August. Figure 3 shows the results of eight surveys conducted by five media outlets-Japan Broadcasting Cooperation (nihonhosokyokai, NHK), Asahi Newspaper, Yomiuri Newspaper, who each conducted two surveys, Kyodo News, and Nikkei Newspaper, who each conducted one.

\footnotetext{
17 See the website campaign for 10 million people's action. Available at http://sayonara-nukes.org/zero_pubcm/(the final access is on March 3, 2016).

18 The answer "Other" means that the respondents have opinions that are different from the three options or that they have no special opinion.
} 
In the media-conducted opinion polls, different from the government-sponsored questionnaires, respondents chose the most agreeable one out of the three options.

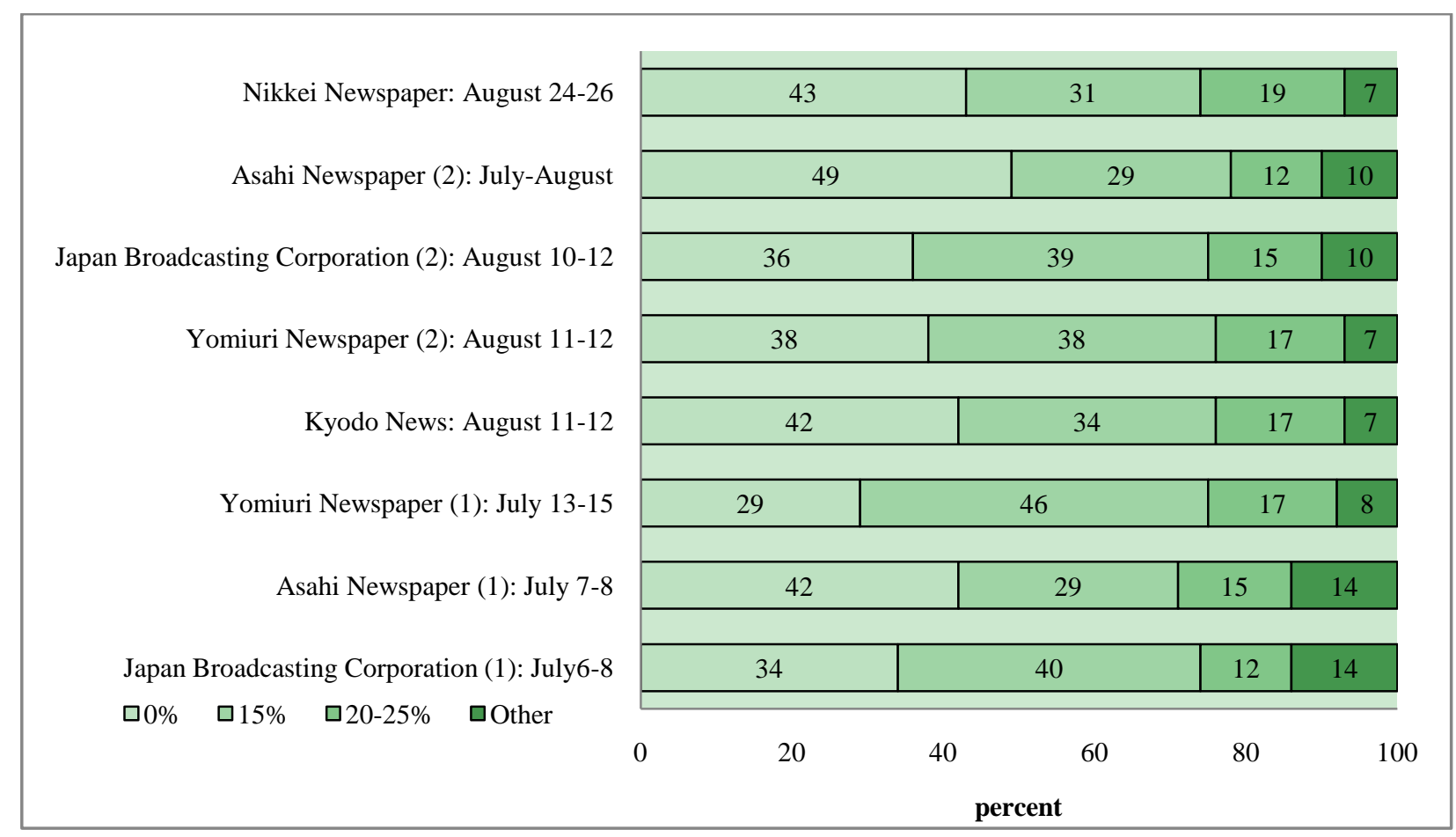

Figure 3. Opinion polls conducted by different media. Sourced from the National Policy Unit, http://www.env.go.jp/council/06earth/y060-110/mat01_1.pdf.

Despite their different results, none of the surveys show that the proportion of respondents who supported Option 0 exceeded 50\%. However, the proportion supporting Option 0 tended to increase in later surveys. In terms of changes between the first and second surveys, the proportion supporting Option 0 was higher in the second surveys than in the first. As Figure 3 shows, Yomiuri Newspaper polls presented an eight-point difference between the first and second surveys, those of Asahi Newspaper presented seven points, and those of Japan Broadcasting Cooperation presented two points. The change between the first and second surveys reflects the government decision on the reactivation of reactors at the Ohi Plant. As noted earlier in this section, reactivation was unpopular with much of the public, who expressed their opposition to the government decision in opinion polls without restraint.

\section{Integrating Diverse Voices Into the National Consensus}

The government invited eight experts on opinion polls, elections, administrative law, and public communication to examine the outcomes of the national debates. They not only discussed the outcomes of the three government-sponsored programs, but also took into account the anti-nuclear movements such as the Friday Rallies and the media-sponsored opinion polls. Their examination meetings, held on August 22, 27, and 28, 2012, were open to the public and broadcast live via the Internet. By considering all opinions that emerged from the government-sponsored national debates, media-conducted opinion polls, and anti-nuclear rallies, the panel of experts put forward the following comments. ${ }^{19}$

19 Information about the examination of national debates is from the National Policy Unit. Available at http://www.cas.go.jp/jp/seisaku/npu/policy09/archive12.html (the final access is on March 4, 2016). 
Approximately $70 \%-80 \%$ supported Option 0 or Option 15 . Many of the supporters for Option 15 additionally wished to create a society without nuclear power after 2030. Thus, the majority of Japanese people wished to abolish nuclear generation in the future. However, they did not reach a consensus on the period in which to achieve this goal. Some wished it to be done as soon as possible, while others believed that it should be a long-term process. The national debates demonstrate that the Japanese public did not focus on a timetable of deconstructing power plants, but rather on a grand vision of a socio-economic system without nuclear power, the feasibility of renewable energy, and the balance between renewable energy and economic growth. The government needed to put forth a realistic policy reflecting the major demands of Japanese people and arrange responses to counter-demands.

Using these comments as a foundation, the Energy and Environment Council soon began to prepare a proposal for the new energy policy. The proposal, titled the "Innovative Energy and Environment Strategic Plan", abbreviated to the nuclear-phase-out plan, specified that the government should pursue a society without nuclear power as soon as possible by establishing green energy sources to cease the operation of all power plants by $2039 .^{20}$ As the Energy Council followed the outcomes of national debates as well as the experts' comments faithfully, it is no wonder that it proposed the phasing out of nuclear power. However, the proposal could not satisfy those who demanded the immediate dismantling of all power plants. In fact, the proposal treated nuclear generation as an important energy source until alternative energies could replace it, although it emphasized that reactors should only be used where their safety is guaranteed. This suggests that nuclear power will remain even after 2040 if alternative energy sources are not sufficiently well-established. Nonetheless, the proposal would have compelled Japan to make dramatic changes to its rigid policy, entrenched by vested interests.

An original version of the proposal included the provision that "the government would put forth a nuclear-phase-out bill to the Diet speedily in order to execute the proposal without hesitation". However, this important sentence was removed from the proposal a day before it was publicized. The Environment and Energy Council planned to open a press conference to publicize the proposal on September 14, 2012. Although the original version had been completed on the night of the 13th, it was revised in the afternoon of the 14th just before the conference. ${ }^{21}$ The final proposal did not refer to lawmaking, instead stating that, "the government will examine how a society without nuclear can be realized". The final proposal was passed to a meeting of the Cabinet, which took responsibility for approving it as a formal government policy. The Cabinet Meeting approved the final proposal on September 19,2012. As the DPJ government failed to give a legal foundation to its nuclear-phase-out plan, there was no guarantee that the new energy plan would be implemented.

\section{Difficulties With the DPJ's Nuclear-Phase-Out Plan}

What caused the overnight change in the proposal? What prevented the DPJ government from moving forward to make a nuclear-phase-out law? Naturally, the Nuclear Village opposed the DPJ's plan, and municipalities with nuclear plants put pressure on the government to withdraw the plan. However, these municipalities' economies depended on the nuclear industry, and the national government subsidized them as a

\footnotetext{
20 Sources the National Policy Anit. Available http://www.cas.go.jp/jp/seisaku/npu/policy09/pdf/20120914/20120914_1.pdf (the final access is on March 4, 2016).

21 This information is based on the present author's own interview with Masakatsu Ota, Editorial Writer of Kyodo News, on December 20, 2013. Mr. Ota informed the present author about the process of this change at the meeting, citing three versions of the proposal. According to these versions, the sentence of lawmaking had remained in two versions on the 13 th and on the morning of the 14th at 8:00, but it was removed from a later version issued on the 14th at 14:00.
} 
reward for suffering these troublesome facilities (Financial Times, 2013). Electric trade unions that were large backers of the DPJ disagreed with the plan because phasing out nuclear power would cause their members to lose their jobs. DPJ Diet members, who came from and had connections with electric trade unions, declined to support the plan (Yamaoka, 2012, pp. 216-218). Huge vested interests in the existing nuclear policy manifested themselves in political inertia, thereby preventing any radical changes. However, these sources of opposition were expected and might have been overcome by job creation, additional subsidies, and rational persuasion.

As mentioned above, the DPJ's plan estimated that even Option 0 would sustain economic growth. Nevertheless, economists and business leaders doubted the relationship between nuclear-free energy sources and sustainable economic growth, as they did not think that renewable energy could compensate for an absence of nuclear power. They were worried about negative effects on the economy, such as diminished supply and increased cost of electricity, and thus criticized the plan as an unrealistic ideal. They also pointed to the potential negative impacts on Japan's goal of $25 \%$ reduction in $\mathrm{CO} 2$ emissions. This goal, they believed, could not be achieved without nuclear power (Mainichi Newspaper, 2012).

The greatest obstacle faced by the plan was a large amount of separated plutonium stocked in the Rokkasho Nuclear Reprocessing Plant. The construction of the Rokkasho Plant started in the late 1980s. Its attached facilities, such as those for uranium enrichment and a landfill site for low-level radioactive waste and the monitoring of high-level nuclear waste, have been in operation since 1992 (Yoshioka, 2012, p. 198). However, owing to frequent problems, the main facility for reprocessing spent-nuclear-fuel is still under construction with its completion expected in $2018 .^{22}$ Separated plutonium has increasingly been accumulated, with the amount reaching nine tons, or enough to produce 1,000 nuclear warheads (The Economist, 2012). In 1984, when the LDP government requested Aomori Prefecture as the location of this new plant, the prefecture accepted the request on the condition that Rokkasho would never be a final landfill site for nuclear waste. In 1998, the LDP government further promised the prefecture that when reprocessing was impossible, plutonium would be transferred from Rokkasho to other plants responsible for its disposal (Ota, 2013a). If the phase-out plan were to be carried out, this huge amount of plutonium would be left where it was. On the strength of the condition in 1984 and the promise in 1998, Aomori Prefecture insisted that the prefecture would reject separated plutonium storage unless the DPJ government could offer an alternative to its reprocessing in Rokkasho. Yet the DPJ government had no concrete ideas. The phase-out plan was therefore less feasible if it contained no practical measures to replace reprocessing. This lack of feasibility made the government hesitate to take any major steps forward (Ota, 2013b).

The issue of separated plutonium caused further diplomatic problems. The US, the UK, and France expressed serious concerns about Japan's large stockpile of separated plutonium without any plan for its processing, as it "sent the wrong message to potential nuclear rogue states" (The Economist, 2012). The international community approves of Japan stockpiling plutonium because Japan holds no nuclear weapons and pledges to use plutonium only for reprocessing. If Japan keeps plutonium without any plans for its reprocessing, there is an argument that the international community may in turn fail to compel Iran and North Korea to cease their illicit nuclear activities. The US also disagreed with Japan's renouncement of the nuclear industry, as it would significantly inhibit developments in nuclear technology for the US. Indeed, since the Three Mile Island nuclear accident, the US has suspended construction of new nuclear plants and transferred its nuclear expertise

\footnotetext{
22 The main facility's completion has been postponed more than twenty times and its cost has increased by a factor of three (Yoshioka, 2012, p. 170).
} 
to Japanese companies, such as Hitachi and Toshiba, through links with American companies, such as General Electric and Westinghouse. Thus, the US expressed concern that "Russia and China, rather than Japan and France, would take the lead in nuclear technology" if Japan abandoned nuclear power (The Economist, 2012).

Two American experts on Japan-Richard Armitage, former Ambassador to Japan, and Joseph Nye, International Relations Professor at Harvard University - questioned in their report issued in August 2012 whether the nuclear-phase-out plan could contribute to Japan's national interests (Armitage \& Nye, 2012). Armitage and Nye (2012) noted that "nuclear power still holds tremendous potential in the areas of energy security, economic growth, and environmental benefits" and "[s]afe, clean, responsibly developed and utilized nuclear power continues to be an essential element in Japan's comprehensive security" (p. 3). The viewpoints of these two influential figures represent those of the US government. The DPJ government attempted to show the phase-out plan to the US government just before it announced the proposal. However, the US government failed to support the DPJ's proposal to make the phase-out plan law and invited the DPJ to give the plan some flexibility to allow for future changes (Ota, 2013a). The US government suggested to the DPJ that the 2030 deadline should be "more of an objective than a commitment".

Prime Minister Noda and his cabinet gave up the idea of making the plan law after learning about the US government's disagreement (Ota, 2013a). This pressure from the US government appears to have been an immediate influence on the DPJ's withdrawal of the reference to lawmaking. Yukio Edano, the Minister of Economy, Trade, and Industry at the time, offered a different perspective. In his interview with a news reporter, he stated that, even though a nuclear-phase-out bill was presented to the Diet, it would have been impossible for the DPJ to pass the bill because opposition parties controlled the Upper House; according to this account, the DPJ simply used US disagreement as a pretext for the withdrawal (Ota, 2013a). ${ }^{23}$ In any case, as this paper discusses in the next section, the withdrawal of lawmaking deprived Diet members of any opportunity for meaningful legislative deliberation.

\section{Failure in the Nuclear-Phase-Out Plan}

\section{Legislative Deliberation on the Nuclear-Phase-Out Plan}

The extraordinary Diet session began on October 29, 2012. ${ }^{24}$ In his opening speech, Prime Minister Noda declared that his administration would continue to attempt to complete the nuclear-phase-out by 2039. Opposition Diet members questioned this declaration. For example, Shinzo Abe, the LDP President, questioned whether the DPJ's nuclear-phase-out plan was consistent with the $25 \%$ reduction of $\mathrm{CO}_{2}$ emissions and with sustainable economic growth, stating that he believed it to be unrealistic. Akira Amari, the LDP Policy Chief, criticized the DPJ's plan for causing heightened international security concerns from the separated plutonium stock in Rokkasho and asked Prime Minister Noda why the DPJ government had failed to make the plan law. Like Amari, Shozo Azuma of People's Life First ${ }^{25}$ asked Noda the reason behind the plan's inertia and who

\footnotetext{
${ }^{23}$ Masakatsu Ota, who interviewed DPJ politicians who had been involved in the drafting of the nuclear-phase-out plan, attempted to interview Yoshihiko Noda, the Prime Minister at the time, about the main reason for his withdrawal of lawmaking, but the former Prime Minister declined to meet Ota (sourced from the present author's own interview with Ota in person, on December 20, 2013).

${ }^{24}$ Regarding Diet deliberation in this section, see the Diet record search engine, Available at http://kokkai.ndl.go.jp/(the final access is on 5 March, 2016).

${ }_{25}$ People's Life First was established by 49 Diet members who had left the DPJ due to their opposition to DPJ's decision of an increase in consumption tax in July 2012. The party, however, was dissolved in November 2012 to join the Tomorrow Party of Japan.
} 
had urged him not to make the plan law. Noda avoided giving a direct answer to their questions and instead repeatedly stated that he had made efforts to abolish nuclear power.

During the extraordinary session, three other opposition Diet members took up the nuclear issue; however, their discussions failed to progress the issue. On November 16, 2012, the Prime Minister declared an unexpected dissolution of the Lower House, bringing the Diet session to a close. The legislative deliberation on the nuclear-phase-out plan was far less active than the national debates. The short length of this session may have affected the deliberative stagnation in the Diet. More importantly, the LDP, the largest opposition party, treated the phase-out plan as a lower priority than other items on the agenda, such as fiscal deficit, social security tax reform, the Trans-Pacific Strategic Economic Partnership Agreement (TPP), and the reappointment of Lower House seats. During Diet discussions, the largest opposition party typically takes the initiative and selects the agenda for questioning the ruling party, which answers solely to them. Motohisa Furukawa, the Minister of Policy Unit at the time, who was in charge of the national debates, claimed that the DPJ was deprived of an opportunity to debate the phase-out plan with opposition parties. ${ }^{26}$ The LDP, the main player for initiating the discussion, seemed to avoid an intensive debate on the plan because of its pro-nuclear stance.

\section{Overturn of the Nuclear-Phase-Out Plan}

Internal and external difficulties prevented the DPJ from making the nuclear-phase-out plan law. However, the DPJ might have had an opportunity to complete its plan if it had gained public support. As a result of the dissolution of the Lower House, the general election was held on December 16, 2012. The most important issue at this election was not nuclear power but the economy. Before the election campaign began, the LDP President, Abe, had attacked the DPJ for its failure to boost the economy, and proposed an aggressive economic plan to pull Japan out of deflation. Abe's economic plan, called Abenomics, had three main components: a monetary easing policy, a fiscal stimulus plan, and an economic growth strategy. While it had yet to be implemented and was merely rhetoric, Abenomics was expected raise Japanese stock prices, a fact that increased the popularity of Abe and the LDP.

Throughout the election campaign, the DPJ placed the nuclear-phase-out plan as one of the five key issues. By contrast, the LDP pledged to keep some level of nuclear generation, attributed a lower priority to the nuclear issue, and put economic growth as its top priority. The LDP was the only party among the main parties in this election to advocate the necessity of nuclear generation, and Japanese voters were more attracted by the LDP's aggressive economic plan than they were by the DPJ's nuclear-phase-out plan.

As they had suffered a long-standing recession and Abe's proposal provided a viable option for economic recovery, the Japanese public expected Abe and his party to be capable of putting the Japanese economy back on track. By contrast, many voters were angry with the DPJ, believing the party to have betrayed their trust by breaking many of its pledges, including a promise to remove the US army bases in Okinawa, which it had failed to fulfill, and enacting a law to increase consumption tax by 3\% in August 2012. Not only had the DPJ previously made an electoral pledge not to increase the tax, but voters had also necessarily perceived the tax increase as having negative impacts on the economy.

In these respects, it was unsurprising that the LDP swept to victory over the DPJ. Whereas the LDP won the majority of seats, increasing its Lower House members to 294 from 118 in the previous election, the DPJ lost the majority of its seats. As a result, the DPJ became the second opposition party. In short, voters chose

\footnotetext{
${ }^{26}$ Sourced from the present author's own interview with Mr. Furukawa in person, on November 11, 2015.
} 
economic growth rather than the promise of a nuclear-free society. After gaining power, the LDP declared that nuclear power was necessary for the country's economic growth.

\section{Contradictory Public Demands}

The same people that had demanded the creation of a nuclear-free society only several months before elected a pro-nuclear figure as their leader. What caused this sudden change of mind? To explore this question, it is necessary to eliminate social desirability bias, the effects of which are the focus of Ryosuke Imai's (2013) examination of the changes in the opinion polls on nuclear power plants. Between April and August 2012, according to Imai (2013, p. 35), the proportion of respondents who thought the number of nuclear plants should be reduced increased by $20 \%$ and the proportion of respondents who thought the existing number should be retained decreased by $20 \%$. Among those who shifted their opinions towards reducing the number of plants, Imai (2013, p. 36) explained that some only pretended to change their minds because they viewed the rejection of nuclear power as socially desirable. As described in the previous section, the rise of the Friday Rallies coincided with an increase in the proportion of respondents who chose Option 0 in the government's questionnaires and the media's opinion polls. From April to August 2012, negative attitudes toward nuclear power propagated rapidly throughout Japanese society. In this climate, people were more likely than usual to support a nuclear-free framework.

The social desirability bias suggests that at the peak of Japan's nuclear-rejecting climate, the substantive number of the opponents of nuclear power was less than the descriptive number (Imai, 2013). It is therefore more accurate to exclude the effects of the social desirability bias. Two surveys of public opinions on nuclear power, conducted by the Japan National Broadcast Association in March 2012 and again in March 2013, provide the data that permit the exclusion of social desirability bias. The two surveys include the same questions regarding the extent of the individual's interest in energy issues (Q1) and the government's treatment of nuclear plants (Q2), as shown in Table 3.

Table 3

Changes in Public Opinions on Nuclear from 2012-2013

\begin{tabular}{lll}
\hline Q1: How interested are you in nuclear issues? & & \\
\hline Answer & March 2012 (N=1585) & March 2013 (N=1655) \\
\hline Very much & $33.8 \%$ & $29.1 \%$ \\
To some extent & $54.9 \%$ & $56.5 \%$ \\
Not so much & $8.7 \%$ & $11.7 \%$ \\
Not at all & $1.4 \%$ & $1.6 \%$ \\
I don't know or no answer & $1.3 \%$ & $1.0 \%$ \\
\hline Q2: How should the government treat nuclear plants? & & March 2013 \\
\hline Answer & March 2012 & $1.8 \%$ \\
\hline The government should increase the number of plants & $1.7 \%$ & $25.2 \%$ \\
The government should keep the existing number of plants & $21.3 \%$ & $40.5 \%$ \\
The government should decrease the number of plants & $42.8 \%$ & $27.6 \%$ \\
The government should abolish all plants & $28.4 \%$ & $4.9 \%$ \\
I don't know or no answer & $5.1 \%$ & \\
\hline
\end{tabular}

Note. Surveyed by the Japan National Broadcast Association (nihonhosokyokai, NHK).

The upper matrix of Table 3 shows that respondents' interest in energy issues declined slightly a year later. The proportion of respondents who answered that they were very interested in energy issues decreased by 4.7 
points, while the proportions of those who answered that they were interested "to some extent", "not so much", and "never" increased by $1.6,3$, and 0.2 points, respectively. When combining the answers of "very much" and "to some extent", the proportion of respondents who were interested in energy issues, regardless of their degree of interest, decreased from $88.7 \%$ to $85.6 \%$ over the course of that year. The bottom matrix of Table 3 describes the question relating to the governmental treatment of nuclear plants. The proportion of respondents who answered that the government should abolish all plants declined by 0.8 points and the proportion that answered that the government should decrease the number of plants declined by 2.3 points. The proportion of respondents who wished to increase the number or keep the existing number of plants increased by 0.1 and 3.9 points, respectively.

The surveys suggest that, despite their preference for a pro-nuclear leader, many Japanese people still wished for a society without nuclear power and that only a few people had changed their minds to support nuclear power. One reason for such an inconsistent decision was the growing complexity of public demands. As mentioned in the previous section, the respondents or participants in the government-sponsored national debates chose their option from the three based on their relative judgment. In the government-sponsored questionnaires, many respondents gave their highest score to Option 0 , but also gave a somewhat positive evaluation to Option 15 or Option 20-25. Masao Matsumoto, an expert on the public consciousness of politics, who took part in the meetings examining the national debates, noted that, because choices often stem from emotional concessions, conflicts, or ambiguities, individuals make choices according to their personal condition, circumstances, and feelings at a given time. ${ }^{27}$

Following Matsumoto's view, the discrepancy between the anti-nuclear demands of the Japanese people and their voting behaviors can be interpreted as the result of paradoxical personal wishes, instead of the result of changes of mind. Japanese people demanded not only a shift towards a nuclear-free society, but also the creation of a strong economy. In the general election of December 2012, however, voters were forced to choose between these issues. Consequently, they prioritized economic recovery over nuclear-phase-out. However, if the public had not suffered from severe economic stagnation, they might have given priority to a nuclear-phase-out, as voters for the LDP did not always approve of nuclear power. An opinion poll conducted by Asahi Newspaper on June 8-9, 2013 asked the subjects whether they agreed with newly appointed Prime Minister Shinzo Abe's plan to use nuclear power to improve the economy (see Table 4).

Table 4

\section{Japanese People's Support for Abe's Plan to Use Nuclear Power}

Q: Prime Minister Shinzo Abe announced his plan for the active use of nuclear power to improve the economy. Do you agree or disagree with his plan?

\begin{tabular}{llll}
\hline & Agree & Disagree & I don't know or no answer \\
\hline Supportive of the Abe administration & $35 \%$ & $51 \%$ & $14 \%$ \\
Not supportive of the Abe administration & $12 \%$ & $79 \%$ & $9 \%$ \\
Total & $27 \%$ & $59 \%$ & $14 \%$ \\
\hline
\end{tabular}

Note. Surveyed by Asahi Newspaper, on 8-9 June $2013(N=1781)$.

In Table 4, the upper matrix represents respondents who supported the Abe administration, and the middle matrix represents those who did not support it. Naturally, the proportion of respondents who did not support the

\footnotetext{
27 Sourced from the present author's own interview with Masao Matsumoto in person on October 9, 2013. Matsumoto is Professor of Political Science at Saitama University, doing research on opinion polls relating public party support.
} 
Abe administration and also disagreed with Abe's pro-nuclear plan was high. Among the respondents who supported his administration, however, only 35\% agreed with his plan. The data suggest that those who knew that their two demands were incompatible prioritized economic growth over nuclear-phase-out. Voters' prioritization of the economy was therefore the reason for the triumph of the pro-nuclear leader over the anti-nuclear one.

\section{Concluding Remarks}

In summer 2012, Japanese society experienced a turning point. The DPJ government implemented the national debates on nuclear generation, providing ordinary citizens with an opportunity to be involved in policymaking. Through the national debates, the anti-nuclear rallies, and public opinion, the government put forth the nuclear-phase-out plan to create a nuclear-free society. However, the phase-out plan was shelved due to internal and external difficulties that blocked its implementation; it was finally overturned by a regime change.

A less-than-feasible policy is unlikely to be instituted as a government policy. Strong feasibility is an important condition for opening "policy windows" (Kingdon, 1984, pp. 174-204). Not only internal pressure but also external advantage in the policymaking process weakened the feasibility of the phase-out plan. In an increasingly globalized world, a country can hardly make a political decision solely on the strength of a national consensus. Moreover, policies are often interrelated. Japan's nuclear policy was closely interlinked with foreign policy and local governance, as well as economic and industrial policies.

Contradictory demands from the public are not uncommon in Japanese politics. For example, most Japanese people hope for improved social welfare services but may disagree that an increase in taxes is necessary to fund such a program. Socio-economic development increases people's demands for public services as economic affluence creates greater material demands, such as a higher standard of living. However, social advancement inspires non-material or intangible demands, like cultural development and an environmentally friendly lifestyle. As a matter of course, these demands often directly oppose one another, although this does not create political problems, as it is democratically healthy for the public to feel that they are able to express their demands freely and openly. The problem is not the public attitudes but the political response. Above all, legislative deliberations are important to the adjustment of competing policies. Serious legislative deliberation could help people to understand the issue at hand, the best solution, and how best to implement the solution. Japanese legislators made little effort to discuss the nuclear-phase-out sincerely. A lack of legislative deliberations was the most difficult obstacle to the creation of a non-nuclear society.

The national debates and the general election urged the public to make a comparative judgment. Therefore, when the national debates reached the conclusion that nuclear power must be phased out and when the LDP became more preferable than the DPJ in the general election, many Japanese people chose Option 0 and the LDP, respectively, despite supporting other Options or the DPJ to a lesser extent. Citizens' participation in policymaking could supplement legislative representation by ensuring their voices are sincerely heard by legislators, and thus contributing to strengthen democratic politics. That said, civic participation alone is not enough to complete policymaking. Legislative representatives assess and coordinate public demands through the process of legislative deliberation. Once a decision has been made to prioritize one option over the others, the supporters of the other options need to be convinced to accept the decision. The more diverse the voices are that emerge from civic participatory activities, the more necessary the legislative deliberations. 


\section{References}

Armitage, R. L., \& Nye, J. S. (2012). The U.S.-Japan alliance: Anchoring stability in Asia: A report of the CSIS Japan Chair. Retrieved from http://www.quotaproject.org/publications/Quotas_LA_Report.pdf

Connolly, W. E. (1993). The terms of political discourse (3rd ed.). Oxford \& Cambridge: Blackwell.

Crozier, M., Huntington, S. P., \& Watanuki, J. (1975). The crisis of democracy: Report on the governability of democracies to the trilateral commission. New York: New York University Press.

Dalton, R. (2000). Value change and democracy. In S. J. Pharr and R. D. Putnameds (Eds.), Disaffected democracies: What's troubling the trilateral countries? (pp. 252-69). New Jersey: Princeton University Press.

Eto, M. (2008). Vitalizing democracy at the grassroots: A contribution of post-war women's movements in Japan. East Asia: An International Quarterly, 25(2), 115-143.

Financial Times. (2013). Doubts cast over Japan nuclear phase-out. Retrieved from http://www.ft.com/cms/s/0/1fc5fe9a-1916-11e2-af4e-00144feabdc0.html\#axzz3AeQIKQf6

Hangenpatsu undo zenkokurenrakukai (National liaison association for anti-nuclear movements). (1997). Hangenpatsu undo mappu (Map of anti-nuclear movements). Tokyo: Ryokufushuppam.

Imai, R. (2013). Genpatsu no zehi wo meguruseron no doko (A trend in opinion polls on nuclear reliance). In J. Saito, N. Kawai, \& R. Imai (Eds.). Genpatsuseisaku wo kangaerumittsu no shiten (Three perspectives on thinking nuclear policy). Tokyo: Wasedadaigakushuppanbu.

Inglehart, D. (1999). Postmodernization erodes respect for authority, but increases support for democracy. In P. Norris (Ed.), Critical citizens: Global support for democratic government (pp. 236-56). Oxford \& New York: Oxford University Press.

Kingdon, J. W. (1984). Agendas, alternatives, and public policies. Harper Collins Publishers.

Kitada, J. (2013). Keizokuchosademirugenshiryokuhatsudennitaisuruseron (Public opinions on nuclear power generation measured in continuous polls). Nihon genshiryokugakkaiwabunzasshi (Japanese Journal of the Atomic Energy Society of Japan), 12(3), 177-196.

Mainichi Newspaper. (2012). genpatsu zero hoshin, seifuzaikaifukamarumizo (The phase-out-plan widens a gap between the DPJ government and business executive groups). Issued on September 18.

National Policy Unit. (2012). Policy options for energy and environment. Retrieved from http://www.env.go.jp/council/06earth/y060-110/mat01_1.pdf

Noma, Y. (2012). Kinyobikanteimaekogi (Protests in front of the Prime Minister Office on Fridays). Tokyo: Kawadeshoboshinsha.

Ota, M. (2013a). Mohitotsu no shinwa: bei no atsuryoku (Another mythology: A pressure from the USA). In Ehime Shimbun (p. $3)$.

Ota, M. (2013b). Mohitotsu no shinwa: saishoriminaoshi (Another mythology: A revision to reprocessing). Ehime Shimbun (p. 3).

Pharr, S. J., \& Putnam, R. D. (2000). Disaffected democracies: What's troubling the trilateral countries? Princeton, New Jersey: Princeton University Press.

Samuels, R. J. (2013). 3.11: Disaster and change in Japan. Ithaca: Cornell University Press.

Skinner, Q. (1988). Meaning and understanding in the history of ideas. In J. Tully (Ed.), Meaning and context: Quentin Skinner \& his critics. New Jersey: Princeton University Press (pp. 29-67).

Suzuki, K. (2012a). 'Anzenshinwa' no shakaitekihaikei (Backdrop behind the myth of nuclear safety). In Fukushima genpatsujikodokuritsukenshoiinkai (The independent committee for examining the Fukushima Disaster) (pp. 323-334) Chosa/kenshohokokusho (Report on the examination results), Tokyo: Discover 21.

Suzuki, K. (2012b). Anzenkisei no gabanasu (regulation of nuclear safety). In Fukushima genpatsujikodokuritsukenshoiinkai (ed.). Chosa/kenshohokokusho (pp. 292-321).

The Economist. (2012). Rokkasho and a hard place. Retrieved from http://www.economist.com/news/asia/21566018-governments-fudge-its-nuclear-future-remains-unconvincing-rokkasho-andhard-place

Yamaoka, J. (2012). Genpatsu to kenryoku (Nuclear and power). Tokyo: Chikumashobo.

Yoshioka, H. (2012). Shinpan genshiryoku no shakaishi (Social history of nuclear power). Tokyo: Asahishimbunshuppam. 